\title{
Spatial analysis of canine leishmaniasis in an area of transmission of the semi-arid region of the State of Paraíba, Brazil
}

\author{
Análise espacial da leishmaniose canina em uma área de transmissão do \\ semiárido paraíbano, Brasil
}

Raizza Barros Sousa Silva1* (D); Laysa Freire Franco-Silva; Diana Azevedo Lima²; Angélica Beatriz Araújo de Andrade Freitas²; Walter Massa Ramalho3; Marcia Almeida de Melo ${ }^{1 *}$

\footnotetext{
${ }^{1}$ Pós-graduação em Ciência e Saúde Animal, Universidade Federal de Campina Grande - UFCG, Patos, PB, Brasil 2 Unidade Acadêmica de Medicina Veterinária, Universidade Federal de Campina Grande - UFCG, Patos, PB, Brasil ${ }^{3}$ Faculdade de Medicina, Universidade de Brasília - UNB, Brasília, DF, Brasil
}

How to cite: Silva RBS, Franco-Silva LF, Lima DA, Freitas ABAA, Ramalho WM, Melo MA. Spatial analysis of canine leishmaniasis in an area of transmission of the semi-arid region of the State of Paraíba, Brazil. Braz J Vet Parasitol 2021; 30(1): e018620. https:// doi.org/10.1590/S1984-296120201089

\begin{abstract}
Visceral leishmaniasis is a widely distributed zoonosis and canine infection is an important indicator of risk for the occurrence of the disease in humans. The goal of this analysis was to study the spatial clustering of canine leishmaniasis $(\mathrm{CL})$ in the municipality of Santa Luzia, state of Paraíba. For this, 749 samples of canine plasma were tested using three serological tests. The dog was considered positive if it reacted in two serological tests. The location of the residences was performed with a Global Positioning System receiver (GPS Garmin ${ }^{\circledR}$ eTrex 30 ), and used to perform georeferencing and spatial analysis. The prevalence of CL was $15.49 \%$ and it was observed that most cases of the urban area were concentrated in the Frei Damião neighborhood, on the outskirts of the city, where a high-risk cluster for the occurrence of the disease was formed $(p=0.02 ; R R=2.48$ ). No statistically significant cluster was observed in rural areas. $\mathrm{CL}$ is widely distributed in the municipality of Santa Luzia in a heterogeneous manner and with a tendency to urbanization. The areas identified with high prevalence and highest risk should be prioritized to maximize the efficiency of the Visceral Leishmaniasis Surveillance and Control Program and minimize the chance of new canine and human cases.
\end{abstract}

Keywords: Epidemiology, Geographic Information Systems, Leishmania infantum, One Health, zoonosis.

\begin{abstract}
Resumo
A leishmaniose visceral é uma zoonose amplamente distribuída, e a infecção canina é um importante indicador de risco para a ocorrência da doença em humanos. O objetivo foi estudar o comportamento espacial da leishmaniose canina (LC) no município de Santa Luzia, estado da Paraíba. Para tal, 749 amostras de plasma canino foram testadas por meio de três técnicas sorológicas. O cão seria considerado positivo se apresentasse duas sorologias reagentes. A localização das residências foi realizado pelo receptor de Sistema de Posicionamento Global (GPS Garmin $\circledast$ eTrex 30) e usado para a realização do georreferenciamento e análise espacial. A prevalência da LC foi de $15,49 \%$ e observou-se que a maioria dos casos de LC da zona urbana estava concentrada no bairro Frei Damião, localizado na periferia da cidade, onde se formou um cluster de alto risco para ocorrência da doença ( $p=$ 0,$02 ; R R=2,48$ ). Nenhum cluster estatisticamente significativo foi observado na zona rural. A LC está amplamente distribuída no município de Santa Luzia, porém de forma heterogênea e com tendência à urbanização. As áreas identificadas com intensa prevalência e maior risco devem ser priorizadas para maximizar a eficiência do Programa de Vigilância e Controle da Leishmaniose Visceral e minimizar a chance de novos casos caninos e humanos.
\end{abstract}

Palavras-chave: Epidemiologia, Sistemas de Informação Geográfica, Leishmania infantum, Saúde Única, zoonose.

Received August 11, 2020. Accepted November 30, 2020.

*Corresponding authors: Raizza Barros Sousa Silva; Marcia Almeida de Melo. E-mail: raizzabss@hotmail.com; marcia.melo@ufcg.edu.br 


\section{Introduction}

Visceral leishmaniasis (VL) is a zoonosis caused by the protozoan Leishmania infantum which affects humans, canids, and other mammals (WHO, 2010). The VL has a broad worldwide distribution and $96.00 \%$ of the VL cases on the American continent occur in Brazil, mainly in the Northeast Region (Brasil, 2014; PAHO, 2018). Despite the usage of control strategies proposed by the Visceral Leishmaniasis Surveillance and Control Program (PVCLV) (Brasil, 2014), in general, there is no decrease in the number of cases of human and canine leishmaniasis, and the disease is expanding in Brazil, with notification of cases in areas where VL had not yet been reported (Moreira et al., 2004; Oliveira et al., 2008; Campos et al., 2017).

To increase the effectiveness of the control strategies, the Health Ministry recommends that the actions should be distinct for each epidemiological situation and that the areas with more serious epidemiological situation must be prioritized (Brasil, 2014). In this sense, spatial analysis tools may help in epidemiological research and improve the use of public resources, since enable the mapping of the areas where the cases occur, characterizing and quantifying, and allowing a greater recognition of the local reality (Brasil, 2006; Pavarini et al., 2008; Barbosa et al., 2014; Ribeiro et al., 2014).

Bearing in mind that canine infection is an important indicator of risk for the occurrence of human VL (Faye et al., 2011) and that the epidemiological aspects may signalize important actions for controlling the disease to local surveillance agencies, the objectives of this research were to map the distribution of canine leishmaniasis (CL) and to detect spatial clusters to identify the areas at risk for VL in the municipality of Santa Luzia, Paraíba.

\section{Material and methods}

\section{Ethical considerations}

The work was approved by the Ethics Committee of the Health and Rural Technology Center (CSTR), Federal University of Campina Grande (UFCG), under the protocol n. 283/2015.

\section{Area of study}

The cross-sectional study was conducted in the urban and rural areas of Santa Luzia ( $06^{\circ} 52^{\prime} 18^{\prime \prime}$ S and $\left.36^{\circ} 55^{\prime} 18^{\prime \prime} \mathrm{W}\right)$, in the Brazilian semi-arid, located in the immediate and intermediate geographical regions of the municipality of Patos, Paraíba (IBGE, 2017).

The urban area is composed of six neighborhoods and the rural area has seven census sectors (Figure 1). Santa Luzia is characterized by presenting great irregularity in its pluviometric regime, with annual averages of about $550 \mathrm{~mm}$, and rainfall concentrated during the months of January to April. The temperature records show values which range between $20^{\circ} \mathrm{C}$ to $34^{\circ} \mathrm{C}$, with an annual average of $25^{\circ} \mathrm{C}$. It has an area of $455 \mathrm{~km}^{2}$ and a population of 15,341 inhabitants, more than $90 \%$ of whom live in the urban area, according to estimates by the Brazilian Institute of Geography and Statistics (IBGE) in 2016 (IBGE, 2020).

\section{Sample size}

Considering the existence of one dog for every seven inhabitants, the estimated canine population was of 2,191 . The size of sample was determined by the simple random sample calculation, proposed by Thrusfield (2007), considering an expected prevalence of $50 \%$, confidence level of $99 \%$ and sampling error of $4 \%$.

\section{Sample collection}

The collections were carried out between July 2015 and July 2016. Dogs older than six months and without distinction of either race or sex were included in the study. The sampling in the urban area was carried out by convenience, a collection points were set up in each neighborhood. In the rural area, the sampling was by conglomerates, and the collection was conducted in 16 communities pre-selected by random raffle and were contemplated all the houses and all the dogs of the raffled localities.

The blood was obtained by jugular or cephalic venipuncture. A total of $5 \mathrm{~mL}$ of blood was immediately deposited in a tube containing $4 \%$ sodium citrate. After the collection, the samples were centrifuged at 2000 rotation per 


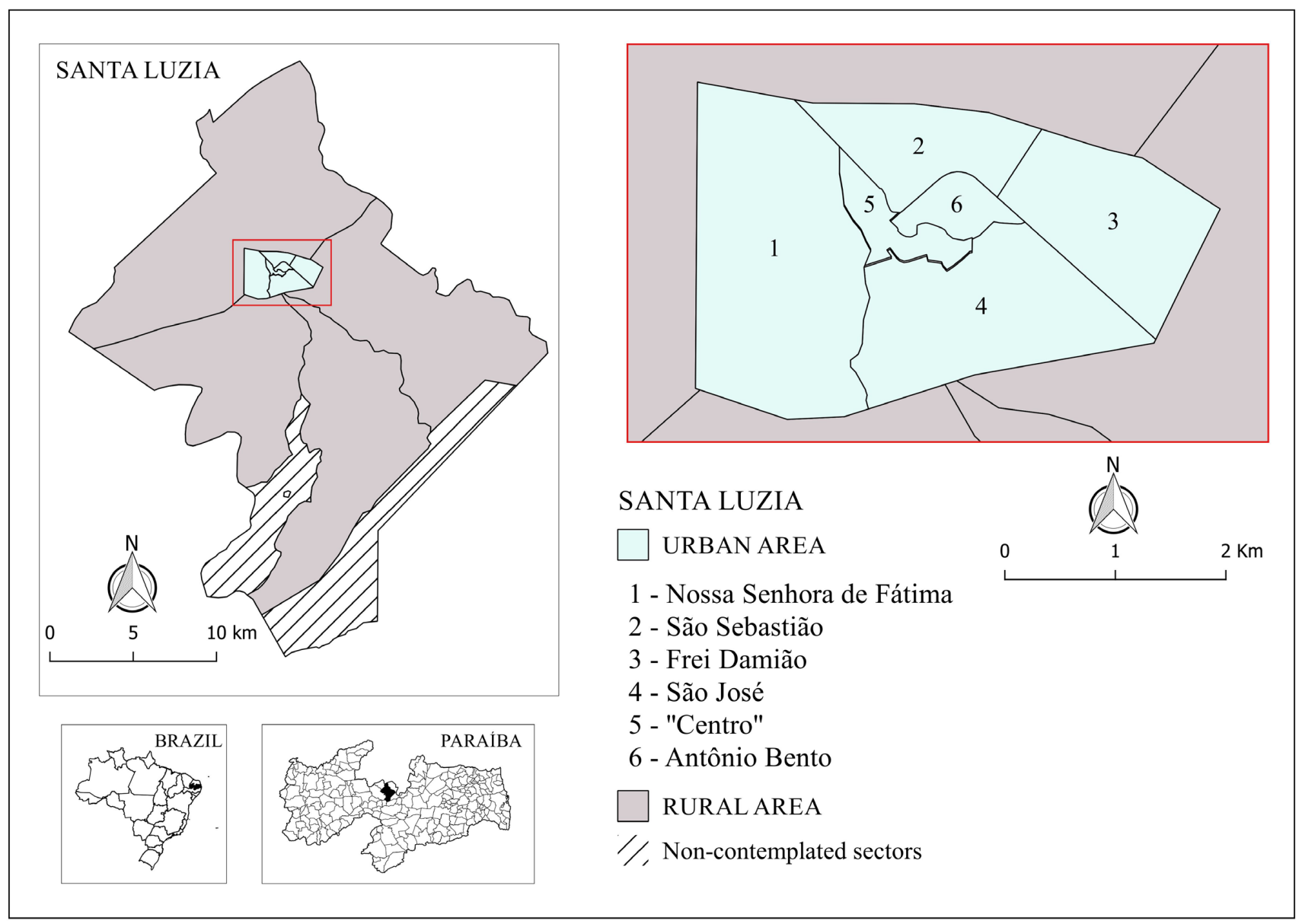

Figure 1. Geographic location of the municipality of Santa Luzia, Paraíba, Brazil. Highlight for the urban area (red rectangle) and its neighborhoods.

minute (rpm) during 5 minutes at room temperature for the plasma separation, which was stored in microtubes of $1.5 \mathrm{~mL}$, identified and stored at $-20^{\circ} \mathrm{C}$ until serological tests were performed.

\section{Serology}

The serological tests used for the diagnosis of the CL were: ELISA-S7® Kit immunoenzymatic assay (Biogene Indústria e Comércio Ltda., Recife-PE, Brazil); Dual Path Platform rapid immunochromatographic test (TR DPP ${ }^{8}$ LVC, Bio-Manguinhos, Oswaldo Cruz Foundation, Rio de Janeiro-RJ, Brazil); and the IEE-LVC $®$ Kit immunoenzymatic assay (Bio-Manguinhos, Oswaldo Cruz Foundation, Rio de Janeiro-RJ, Brazil) only in the samples that reacted in the TR DPP $囚$. All the assays were conducted following the manufacturer's instructions. To determine the prevalence of $\mathrm{CL}$, the dog was considered positive if it reacted in at least two serological tests.

\section{Georeferencing and spatial analysis}

A Global Positioning System receiver (GPS Garmin $®$ eTrex 30 ) was connected in front of the residence of the dog and the latitude and longitude were recorded in the questionnaire. The coordinates obtained with the GPS receiver were spatially mapped with the Google Earth 5.0 program.

The spatial representation of the cases of $\mathrm{CL}$ and their statistical analysis were carried out using the QGIS 2.18.22 and SaTScan 9.4 software. The georeferenced data was inserted in the digitized cartographic base of the municipality, obtained from the site of the IBGE, using the official datum of Brazil, SIRGAS 2000 (Geocentric Reference System for the Americas), and coordinate system UTM zone 24S.

A thematic map of the municipality was made detailing the census sectors (rural areas) and neighborhoods (urban area) based on the prevalence rate. Statistical analysis of the estimation of density curves was also performed by 
Kernel map through the quartic function, which allows examining the variation in spatial point patterns, estimating the density of $\mathrm{CL}$ cases on a scale ranging from very high to very low. Subsequently, the verification of areas in which the $\mathrm{CL}$ was found above the expected, the spatial scanning statistic was used for the detection of clusters using the Bernoulli's model. The measure of association used in the calculation of the clusters was the relative risk. The clusters were generated in two stages according to the size of the high-risk cluster: a) considering up to $50 \%$ of the population at risk and b) considering a radius of up to 300 meters, which is the flight capacity of the phlebotomines (Troncarelli et al., 2012).

\section{Results}

From a total of 749 collected samples, 649 were from the urban area and 100 from the rural area. After the serology was performed, a considerable prevalence of CL was observed: 15.49\% (116/749; Cl 95\%: 12.90-18.08) of the dogs presented anti-Leishmania infantum antibodies, without a significant difference between the prevalence in the urban area (15.87\%; Cl 95\%: 13.06-18.68) and rural area (13.00\%; CI 95\%: 6.41-19.59).

The CL was widely distributed in the municipality of Santa Luzia (Table 1 and Figure 2). It can be observed in Table 1, that there were cases in all the neighborhoods of the urban area, however the one which presented the highest prevalence was the Frei Damião with 26.23\% (32/122), followed by the São José neighborhood, 18.55\% (41/221). In the central neighborhoods, Nossa Senhora de Fátima, Antônio Bento and São Sebastião had similar frequency, varying between 9.72 to $9.89 \%$.

Table 1. Discrimination of the prevalence of canine leishmaniasis per locality of the municipality of Santa Luzia, Paraíba, between 2015 and 2016.

\begin{tabular}{ccccc}
\hline Area & Identification (Sector/Neighborhood) & $\mathbf{N}^{\circ}$ of Positives & Total Collected & Prevalence (\%) \\
\hline Urban & Centro & 7 & 72 & 9.72 \\
& Nossa Senhora de Fátima & 8 & 82 & 9.76 \\
& Antônio Bento & 6 & 61 & 9.84 \\
& São Sebastião & 9 & 91 & 9.89 \\
& São José & 41 & 221 & 18.55 \\
Frei Damião & South & 32 & 122 & 0.00 \\
& Southeast & 0 & 11 & 4.00 \\
& Northeast & 1 & 25 & 16.67 \\
& Northwest & 2 & 12 & 19.23 \\
\hline
\end{tabular}

In the rural area, only one census sector did not present any cases of $\mathrm{CL}$ and the frequency in the other sectors varied between $4.00 \%$ in the rural census sector to the Southeast, and $19.23 \%$ in the rural census sector to the Northwest (Figure $2 \mathrm{~A}$ ). Although $\mathrm{CL}$ is widely disseminated in the municipality, the mapping showed heterogeneity in the distribution of the disease, with intense clustering of cases in some areas, such as in the rural census sectors in the Northwest and Northeast, and in Frei Damião and São José neighborhoods (Figure 2B).

This heterogeneity is confirmed by the Kernel map (Figure 3) and by purely spatial scanning statistics using the Bernoulli model (Figure 4). In the Kernel map, it is possible to observe the variation in the pattern of spatial points, estimating the density of $\mathrm{CL}$ cases on a scale ranging from very high to very low, with some areas of very high density being identified, both in urban and rural areas.

Figure 4 shows a cluster ( $\mathrm{A}$ - purple) of risk for $\mathrm{CL}$ in the urban area of Santa Luzia, which covers Frei Damião and part of São José neighborhoods, the same urban area that showed remarkably high density by Kernel density estimation. When it was taken into consideration the flight capacity of the phlebotomines (radius of up to $300 \mathrm{~m}$ ), 

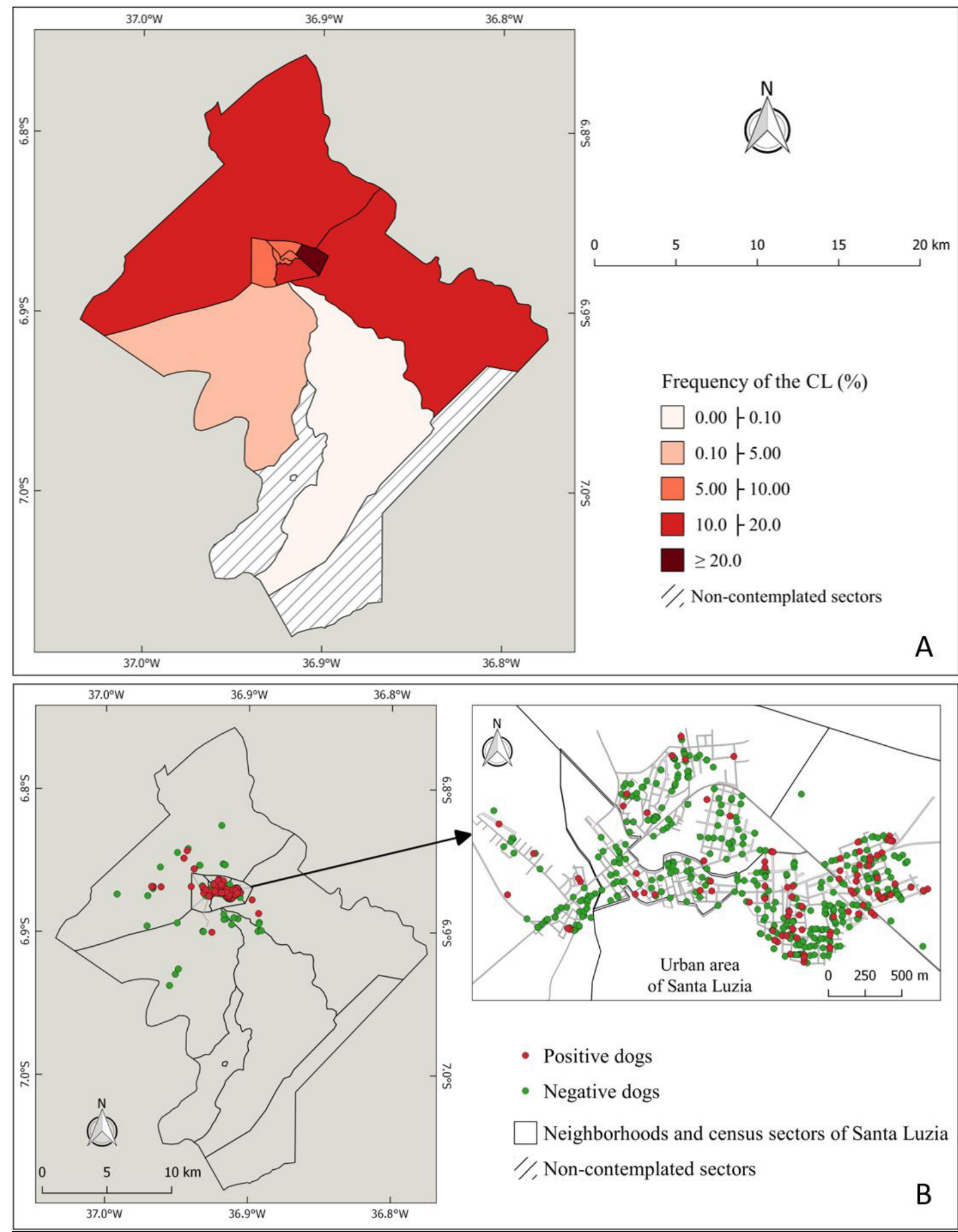

Figure 2. (A) Frequency of canine leishmaniasis (CL) per neighborhoods (urban area) and per census sector (rural area); (B) Georeferencing of the properties according to the serological result for CL in Santa Luzia, Paraíba, Brazil, between 2015 and 2016 (with approximate detail of the urban area).

the cluster (B - yellow) was located only in the Frei Damião neighborhood, on the boundary with the São José neighborhood. There was a risk of canine infection up to 2.62 times higher in cluster A compared to other areas of the municipality. The relative risk and the results of the spatial analysis are described in detail in Table 2. 


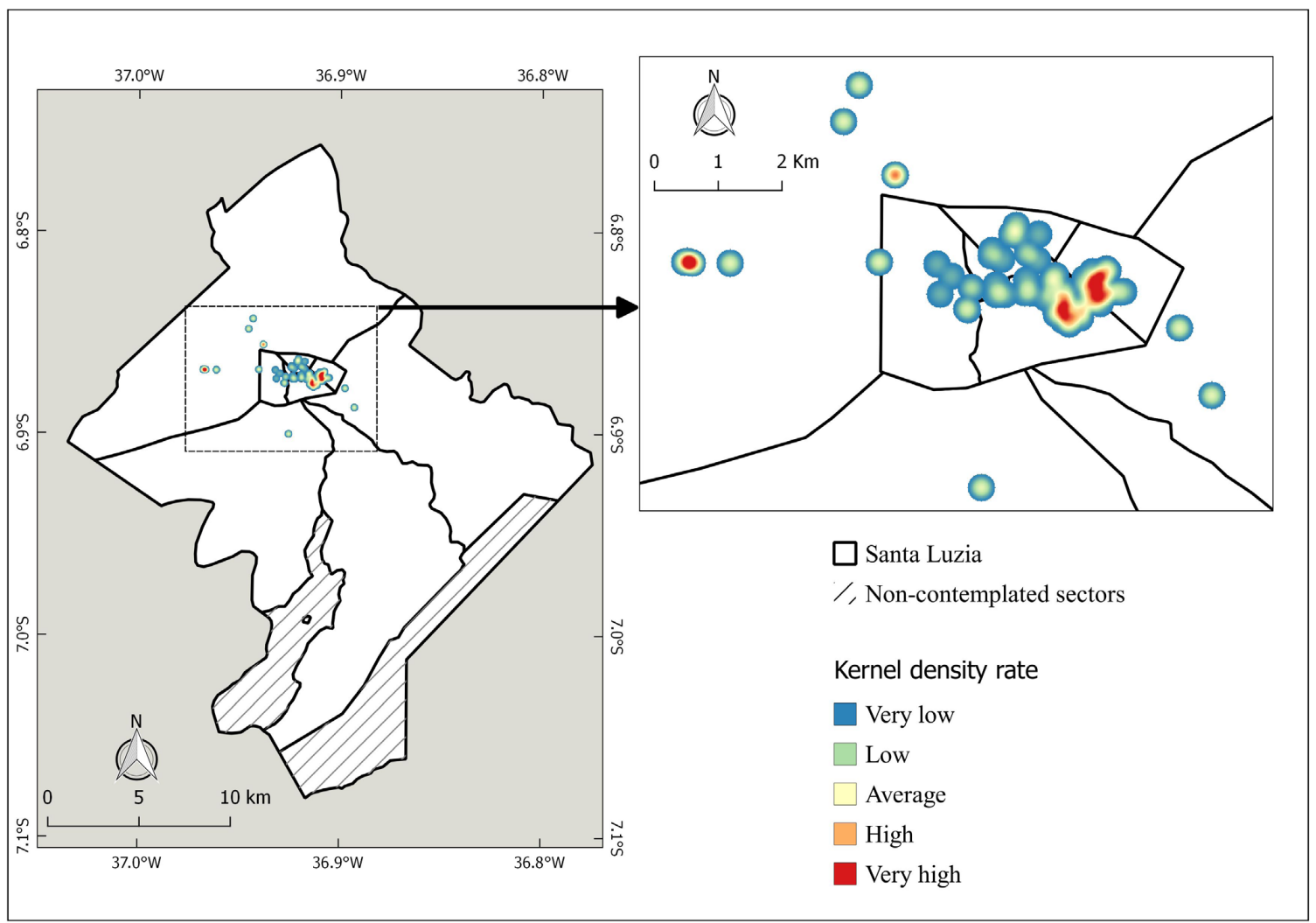

Figure 3. Kernel density map of the canine leishmaniasis in the municipality of Santa Luzia, Paraíba, Brazil (2015-2016).

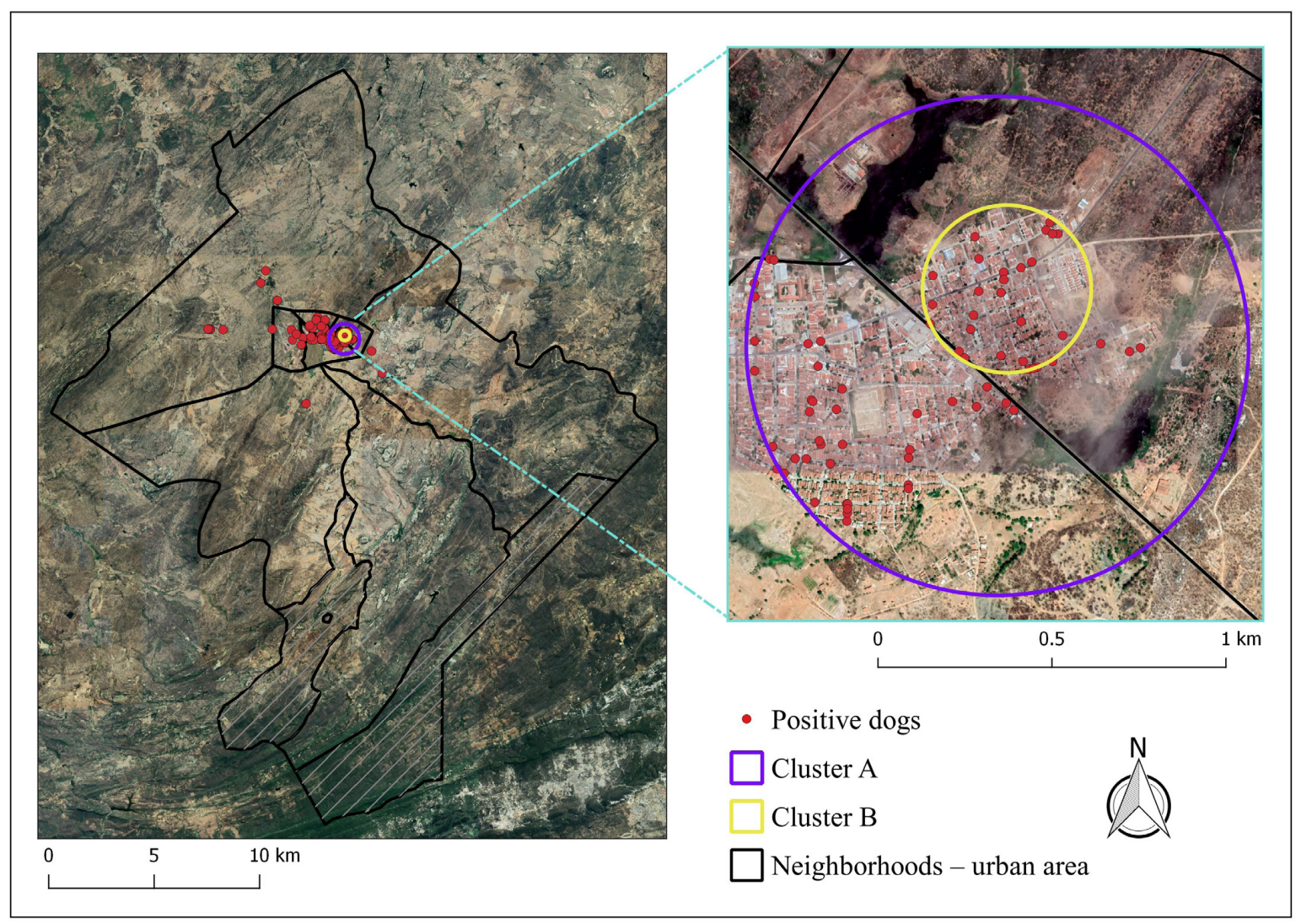

Figure 4. Spatial agglomerates (clusters) of high prevalence of canine leishmaniasis, detected by the spatial scanning statistics, according to the Bernoulli model, in the municipality of Santa Luzia, Paraíba, Brazil (2015-2016). Satellite image data: Google, (c) 2015 CNES / Airbus; Landsat/Copernicus; Maxar Technologies (Google, 2015). 
Table 2. Geographic grouping (cluster) of canine leishmaniasis in Santa Luzia, Paraíba, Brazil (2015-2016).

\begin{tabular}{|c|c|c|c|c|c|c|c|}
\hline \multirow{2}{*}{ Cluster } & \multicolumn{2}{|c|}{ Centroid } & \multirow{2}{*}{ Radius (m) } & \multirow{2}{*}{$\begin{array}{c}N^{\circ} \text {. of cases } \\
\text { observed }\end{array}$} & \multirow{2}{*}{$\begin{array}{l}N^{\circ} \text {. of } \\
\text { expected } \\
\text { cases }\end{array}$} & \multirow{2}{*}{ Relative Risk } & \multirow{2}{*}{ p-Value } \\
\hline & Latitude & Longitude & & & & & \\
\hline$A$ & -6.872330 & -36.909369 & 720 & 74 & 50.85 & 2.62 & 0.001 \\
\hline B & -6.870853 & -36.909129 & 242 & 29 & 14.05 & 2.48 & 0.02 \\
\hline
\end{tabular}

\section{Discussion}

The present study was the first serological survey that covered the canine population of the entire municipality and through which it was possible to know the geographical distribution of CL in Santa Luzia, demonstrating a higher occurrence of cases in the urban area. This finding emphasizes the change in the epidemiological profile of VL in Brazil, which, until the 1970s, had a strictly rural pattern, however, from the following decade its urbanization began to be observed in large urban centers (Cerbino et al., 2009). This same profile is also present in small municipalities in the interior of the country, as observed in Santa Luzia, Paraíba.

Initially, the migration of people and their pets from rural to urban areas was identified as the main responsible for the urbanization process. However, from new studies, it was observed that the form of occupation of the territory (disorganized occupation and unsatisfactory urban services), environmental changes (deforestation and climate change), social and economic factors (precarious living conditions) were more decisive, also associated with the great adaptability of the vector (WHO, 2002; Costa et al., 2005).

The variation in the prevalence of $\mathrm{CL}$ is enormous between Brazilian cities and states, with rates ranging from 0.70\% in Salvador, state of Bahia (Barboza et al., 2009), and 75.30\% in Anastácio in Mato Grosso do Sul (Cortada et al., 2004). This variation may be associated with several factors, such as the geographic region, the population studied and the sensitivity and specificity of diagnostic tests. Prevalences like those found in Santa Luzia were observed in Ipatinga, Minas Gerais (14.80\%) (Lana et al., 2018), and in Petrolina, Pernambuco (19.00\%) (Pimentel et al., 2015). Prevalences like those found in Santa Luzia were observed in Ipatinga, Minas Gerais (14.80\%) (Lana et al., 2018), and in Petrolina, Pernambuco (19.00\%) (Pimentel et al., 2015). In João Pessoa, capital of Paraíba, the seroprevalence of CL was much lower (5.90\%) (Fernandes et al., 2016). In the hinterland of Paraíba, seroprevalence was $20.00 \%$ in Cajazeiras, $16.30 \%$ in Uiraúna and 10.50\% in Sousa (Silva et al., 2018). In Patos, a municipality far 44 km from Santa Luzia, has a similar data, with a prevalence of $18.40 \%$ in the urban area (Fernandes et al., 2016) and $11.33 \%$ in the rural area (Silva et al., 2016). These divergences in the prevalence values demonstrate that different ecosystems favor the maintenance of the vector in different ways, causing heterogeneity in its distribution (França-Silva et al., 2003; Silva et al., 2016). This situation was observed even between different locations in the same municipality, as seen in Santa Luzia. This makes clear the impact that socioeconomic aspects and environmental characteristics have on the occurrence of the disease (Coura-Vital et al., 2011; Ursine et al., 2016; Campos et al., 2017). Specifically, in the state of Paraíba, the municipalities with the highest prevalence of the disease in both humans and dogs are located in the semi-arid region, composed of the Caatinga biome, and also with a lower Human Development Index.

The Frei Damião neighborhood behaved as a high-density and high-risk area for $\mathrm{CL}$, as well as part of the São José neighborhood. Dogs in these neighborhoods are 2.62 times more likely to become infected than dogs in the rest of the county. These neighborhoods are located on the outskirts of the city, which grow in a disorderly manner, have a precarious health infrastructure and are close to remnants of Caatinga vegetation. These areas suffer deforestation for occupation by the low-income population, making it a favorable place for their contact with wild reservoirs and the vector. Aversi-Ferreira et al. (2014) and Cerbino et al. (2009) correlated deforestation through unplanned urbanization with higher frequencies of visceral leishmaniasis, which usually occurs in neighborhoods located in peripheral areas of the city that are expanding, presenting an area of rural/urban transition (peri-urban).

Nossa Senhora de Fátima and São Sebastião neighborhoods had much lower prevalence than Frei Damião and São José neighborhoods, although they have similar socioenvironmental profiles, such as: they are peripheral neighborhoods of recent occupations, with little infrastructure and close to the remaining Caatinga vegetation, and whose population has low family income. This difference may have occurred due to an action taken by the Epidemiological Surveillance in the first half of 2015, after the death of a child by VL in the São Sebastião neighborhood. The Municipal Government intervened with activities close to the human case based on the PVCLV: 
spraying with insecticide, serology of dogs and euthanasia of positive animals. These control actions took place in the same year as this research and covered the neighborhoods of São Sebastião and Nossa Senhora de Fátima.

The peripheries of the cities were pointed as being the areas with the highest concentrations of VL in several works (Cerbino et al., 2009; WHO, 2010; Campos et al., 2017; Carvalho et al., 2018). Rangel \& Vilela (2008) report that the vectors find conditions to multiply and easily adapt to the peridomestic environment, particularly in poor neighborhoods in the outskirts of the cities, exploring the accumulation of organic matter generated by domestic animals and the inadequate sanitation. Ursine et al. (2016) observed that the central region of Araçuaí, Minas Gerais, concentrated the largest number of human and canine cases, but were, in most cases, locations with deficient sanitation infrastructure and populations in precarious living conditions, with large quantities of animals and organic matter. Santa Luzia does not have large intra-urban differences, but it is believed that even small differences can influence the occurrence of the infection, since Centro and Antônio Bento are neighborhoods that have better infrastructure, sanitation and socioeconomic conditions and are among those that presented the lowest frequencies of $\mathrm{CL}$.

The Kernel map shows that the highest density of CL cases in rural Santa Luzia occurred in the northwestern census sector. This area has water mirrors and dense vegetation with the presence of trees and shrubs typical of the Caatinga, which favors the accumulation of organic matter and, consequently, the reproduction and maintenance of the vector (Silva et al., 2005; Nieto et al., 2006). In the same census sector, there are also barns for the breeding of birds, which serve as a breeding ground and source of food for the vector and attract wild animals that are reservoirs of L. infantum (Alexander et al., 2002; Casanova et al., 2013).

The Southeast sector had no case of CL. One hypothesis is that because it is the most deforested area among the census tracts, it disadvantages the interaction between the wild and peridomiciliary cycles of the disease, making it difficult to maintain sandfly populations and the spread of VL (Lainson \& Rangel, 2005). From the public health's point of view, the high density of CL cases found in Santa Luzia is concerning. According to de Araújo et al. (2013) and Lima et al. (2018), in studies conducted in Minas Gerais and Rio Grande do Norte, respectively, the density of the population of infected dogs is directly correlated (positive linear correlation) with the relative risk of contracting human VL. Therefore, this study is useful to prevent new cases also in this population.

For VL strategies to be more effective, the prevention and control measures must be focused on the context of "One Health", in other words, integrated programmes which, besides focusing on the control of vectors and reservoirs, reflect upon the improvement of the infrastructure, environmental management, and mainly, on the health education. It must be kept in mind that health education, from the population to the political community, is the central item for the prevention and control of any disease (WHO, 2010). However, what has happened in recent years is that the actions to control visceral leishmaniasis only happen when a case occurs in humans and around this case, in short, it allows someone to get sick in order to act. Such measures cannot be classified as a "Surveillance and Control Program" and, therefore, should be reviewed and improved.

\section{Conclusion}

Canine leishmaniasis is widely distributed in the municipality of Santa Luzia in a heterogeneous manner and with a tendency to urbanization. The areas identified with high prevalence and highest risk should be prioritized to maximize the efficiency of the Visceral Leishmaniasis Surveillance and Control Program and minimize the chance of new canine and human cases. Spatial analysis proved to be efficient to better understand the disease behavior in the municipality and should be applied, whenever possible, in epidemiological studies.

\section{Acknowledgements}

To the Coordination for the Improvement of Higher Education Personnel (CAPES) for granting the doctoral scholarship. To the Health Agents and Veterinarian of the City Hall of Santa Luzia for their support in the development of the project.

\section{References}

Alexander B, de Carvalho RL, McCallum H, Pereira MH. Role of the domestic chicken (Gallus gallus) in the epidemiology of urban visceral leishmaniasis in Brazil. Emerg Infect Dis 2002; 8(12): 1480-1485. http://dx.doi.org/10.3201/eid0812.010485. PMid:12498667. 
Aversi-Ferreira RAGMF, Galvão JD, da Silva SF, Cavalcante GF, da Silva EV, Bhatia-Dey N, et al. Geographical and environmental variables of leishmaniasis transmission. In: Claborn DM. Leishmaniasis - Trends in epidemiology, diagnosis and treatment. London: InTech; 2014. p. 105-124. http://dx.doi.org/10.5772/57546.

Barbosa DS, Belo VS, Rangel MES, Werneck GL. Spatial Analysis for identification of priority areas for surveillance and control in a visceral leishmaniasis endemic area in Brazil. Acta Trop 2014; 131: 56-62. http://dx.doi.org/10.1016/j.actatropica.2013.12.002. PMid:24342506.

Barboza DCPM, Leal DC, Souza BMPS, Carneiro AJB, Gomes Neto CMB, Alcântara ACD, et al. Inquérito epidemiológico da leishmaniose visceral canina em três distritos sanitários do Município de Salvador, Bahia, Brasil. Rev Bras Saúde Prod Anim 2009; 10(2): 434-447.

Brasil. Ministério da Saúde. Manual de vigilância e controle da leishmaniose visceral. Brasília: Ministério da Saúde; 2014.

Brasil. Ministério da Saúde. Secretaria de Vigilância em Saúde. Fundação Oswaldo Cruz. Abordagens espaciais na Saúde Pública: capacitação e atualização em geoprocessamento em saúde. Brasília: Ministério da Saúde; 2006.

Campos R, Santos M, Tunon G, Cunha L, Magalhães L, Moraes J, et al. Epidemiological aspects and spatial distribution of human and canine visceral leishmaniasis in an endemic area in northeastern Brazil. Geospat Health 2017; 12(1): 503. http://dx.doi. org/10.4081/gh.2017.503. PMid:28555473.

Carvalho AG, Luz JGG, Rodrigues LD, Dias JVL, Fontes CJF. High seroprevalence and peripheral spatial distribution of visceral leishmaniasis among domestic dogs in an emerging urban focus in Central Brazil: a cross-sectional study. Pathog Glob Health 2018; 112(1): 29-36. http://dx.doi.org/10.1080/20477724.2018.1438229. PMid:29460695.

Casanova C, Andrighetti MT, Sampaio SM, Marcoris ML, Colla-Jacques FE, Prado AP. Larval breeding sites of Lutzomyia longipalpis (Diptera: Psychodidae) in visceral leishmaniasis endemic urban areas in Southeastern Brazil. PLoS Neg/ Trop Dis 2013; 7(9): e2443. http://dx.doi.org/10.1371/journal.pntd.0002443. PMid:24069494.

Cerbino J No, Werneck GL, Costa CHN. Factors associated with the incidence of urban visceral leishmaniasis: an ecological study in Teresina, Piauí State, Brazil. Cad Saude Publica 2009; 25(7): 1543-1551. http://dx.doi.org/10.1590/S0102-311X2009000700012. PMid:19578575.

Cortada VMCL, Doval MEC, Souza Lima MAA, Oshiro ET, Meneses CRV, Abreu-Silva AL, et al. Canine visceral leishmaniosis in Anastácio, Mato Grosso do Sul state, Brazil. Vet Res Commun 2004; 28(5): 365-374. http://dx.doi.org/10.1023/B:VERC.0000035014.80785. b7. PMid:15379431.

Costa CHN, Werneck GL, Rodrigues LJ Jr, Santos MV, Araújo IB, Moura LS, et al. Household structure and urban services: neglected targets in the control of visceral leishmaniasis. Ann Trop Med Parasitol 2005; 99(3): 229-236. http://dx.doi. org/10.1179/136485905X28018. PMid:15829132.

Coura-Vital W, Marques MJ, Veloso VM, Roatt BM, Aguiar-Soares RDO, Reis LES, et al. Prevalence and Factors Associated with Leishmania infantum Infection of Dogs from an Urban Area of Brazil as Identified by Molecular Methods. PLoS Neg/ Trop Dis 2011; 5(8): e1291. http://dx.doi.org/10.1371/journal.pntd.0001291. PMid:21858243.

de Araújo VE, Pinheiro LC, Almeida MC, de Menezes FC, Morais MH, Reis IA, et al. Relative risk of visceral leishmaniasis in Brazil: a spatial analysis in urban area. PLoS Neg/ Trop Dis 2013; 7(11): e2540. http://dx.doi.org/10.1371/journal.pntd.0002540. PMid:24244776.

Faye B, Bucheton B, Bañuls AL, Senghor MW, Niang AA, Diedhiou S, et al. Seroprevalence of Leishmania infantum in a rural area of Senegal: analysis of risk factors involved in transmission to humans. Trans R Soc Trop Med Hyg 2011; 105(6): 333-340. http:// dx.doi.org/10.1016/j.trstmh.2011.02.009. PMid:21543098.

Fernandes ARF, Pimenta CLRM, Vidal IF, Oliveira GC, Sartori RS, Araujo RB, et al. Risk factors associated with seropositivity for Leishmania spp. and Trypanosoma cruzi in dogs in the state of Paraiba, Brazil. Rev Bras Parasitol Vet 2016; 25(1): 90-98. http:// dx.doi.org/10.1590/S1984-29612016010. PMid:26982555.

França-Silva JC, da Costa RT, Siqueira AM, Machado-Coelho GL, da Costa CA, Mayrink W, et al. Epidemiolgy of canine visceral leishmaniasis in the endemic area of Montes Claros Municipality, Minas Gerais state, Brazil. Vet Parasitol 2003; 111(2-3): 161-173. http://dx.doi.org/10.1016/S0304-4017(02)00351-5. PMid:12531292.

Google. Coordinates 0652'18"S and 3655'18"W. Santa Luzia, PB: Landsat / Copernicus; Maxar Technologies. 2015.

Instituto Brasileiro de Geografia e Estatística - IBGE. Divisão regional do Brasil em regiões geográficas imediatas e regiões geográficas intermediárias: 2017. Rio de Janeiro: IBGE; 2017. 82 p.

Instituto Brasileiro de Geografia e Estatística - IBGE. Sistema IBGE de Recuperação Automática - SIDRA: Estimativas de População [online]. Rio de Janeiro: IBGE; 2020 [cited 2020 Jan 10]. Available from: https://sidra.ibge.gov.br/tabela/6579 
Lainson R, Rangel EF. Lutzomyia longipalpis and the eco-epidemiology of American visceral leishmaniasis, with particular reference to Brazil - A review. Mem Inst Oswaldo Cruz 2005; 100(8): 811-827. http://dx.doi.org/10.1590/S0074-02762005000800001. PMid:16444411.

Lana RS, Michalsky EM, Lopes LO, Lara-Silva FO, Nascimento JL, Pinheiro LC, et al. Ecoepidemiological aspects of visceral leishmaniasis in an endemic area in the Steel Valley in Brazil: an ecological approach with spatial analysis. PLoS One 2018; 13(10): e0206452. http://dx.doi.org/10.1371/journal.pone.0206452. PMid:30376577.

Lima ID, Lima ALM, Mendes-Aguiar CO, Coutinho JFV, Wilson ME, Pearson RD, et al. Changing demographics of visceral leishmaniasis in northeast Brazil: lessons for the future. PLoS Neg/ Trop Dis 2018; 12(3): e0006164. http://dx.doi.org/10.1371/ journal.pntd.0006164. PMid:29509765.

Moreira ED Jr, Mendes de Souza VM, Sreenivasan M, Nascimento EG, Pontes de Carvalho L. Assessment of an optimized dogculling program in the dynamics of canine Leishmania transmission. Vet Parasito/2004; 122(4): 245-252. http://dx.doi.org/10.1016/j. vetpar.2004.05.019. PMid:15262002.

Nieto P, Malone JB, Bavia ME. Ecological niche modeling for visceral leishmaniasis in the state of Bahia, Brazil, using genetic algorithm for rule-set prediction and growing degree day-water budget analysis. Geospat Health 2006; 1(1): 115-126. http://dx.doi. org/10.4081/gh.2006.286. PMid:18686237.

Oliveira CDL, Morais MHF, Machado-Coelho GLL. Visceral leishmaniasis in large Brazilian cities: challenges for control. Cad Saude Publica 2008; 24(12): 2953-2958. http://dx.doi.org/10.1590/S0102-311X2008001200026. PMid:19082288.

Pan American Health Organization - PAHO. Leishmaniasis: Epidemiological Report in the Americas. Washington: PAHO; 2018.

Pavarini SCI, Mendiondo EM, Montaño M, Almeida DMF, Mendiondo MSZ, Barham EJ, et al. Sistema de informações geográficas para a gestão de programas municipais de cuidado a idosos. Texto Contexto Enferm 2008; 17(1): 17-25. http://dx.doi.org/10.1590/ S0104-07072008000100002.

Pimentel DS, Ramos RAN, Santana MA, Maia CS, Carvalho GA, Silva HP, et al. Prevalence of zoonotic visceral leishmaniasis in dogs in an endemic area of Brazil. Rev Soc Bras Med Trop 2015; 48(4): 491-493. http://dx.doi.org/10.1590/0037-8682-0224-2014. PMid:26132498.

Rangel EF, Vilela ML. Lutzomyia longipalpis (Diptera, Psychodidae, Phlebotominae) and urbanization of visceral leishmaniasis in Brazil. Cad Saude Publica 2008; 24(12): 2948-2952. http://dx.doi.org/10.1590/S0102-311X2008001200025. PMid:19082287.

Ribeiro MA, Albuquerque IMN, Paiva GM, Vasconcelos JPC, Araújo MAVF, Vasconcelos MIO. Georreferenciamento: ferramenta de análise do sistema de saúde de Sobral - Ceará. Sanare 2014; 13(2): 63-69.

Silva AV, Paula AA, Cabrera MA, Carreira JC. Leishmaniose em cães domésticos: aspectos epidemiológicos. Cad Saude Publica 2005; 21(1): 324-328. http://dx.doi.org/10.1590/S0102-311X2005000100036. PMid:15692667.

Silva RBS, Mendes RS, Santana VL, Souza HC, Ramos CPS, Souza AP, et al. Aspectos epidemiológicos da leishmaniose visceral canina na zona rural do semiárido paraibano e análise de técnicas de diagnóstico. Pesq Vet Bras 2016; 36(7): 625-629. http:// dx.doi.org/10.1590/S0100-736X2016000700011.

Silva RBS, Porto ML, Barbosa WO, Souza HC, Marques NFDSP, Azevedo SS, et al. Seroprevalence and risk factors associated with canine visceral leishmaniasis in the State of Paraíba, Brazil. Rev Soc Bras Med Trop 2018; 51(5): 683-688. http://dx.doi. org/10.1590/0037-8682-0429-2017. PMid:30304279.

Thrusfield M. Veterinary epidemiology. Oxônia: Oxford; 2007.

Troncarelli MZ, Carneiro DMVF, Langoni H. Visceral Leishmaniosis: an old disease with continuous impact on public health. In: Lorenzo-Morales J, editor. Zoonosis. London: InTech; 2012. p. 263-282. http://dx.doi.org/10.5772/38680.

Ursine RL, Dias JVL, Morais HA, Pires HHR. Human and canine visceral leishmaniasis in an emerging focus in Araçuaí, Minas Gerais: spatial distribution and socio-environmental factors. Mem Inst Oswaldo Cruz 2016; 111(8): 505-511. http://dx.doi. org/10.1590/0074-02760160133. PMid:27384080.

World Health Organization - WHO. Control of the leishmaniasis [online]. Geneva: WHO; 2010 [cited 2019 Nov 13]. Available from: https://apps.who.int/iris/bitstream/handle/10665/44412/WHO_TRS_949_eng.pdf?sequence=1\&isAllowed=y

World Health Organization - WHO. Urbanization: an increasing risk factor for leishmaniasis. Wkly Epidemiol Rec 2002; 77(44): 365-370. PMid:12428426. 